\title{
BETWEEN (IN)VISIBLE INFLUENCES AND (IM)PURE TRADITIONS: HYBRID CHARACTER OF THE POSTDRAMATIC IN LITHUANIAN THEATRE
}

Summary. Lithuanian theatre has always been known for its visual metaphors and dramaturgy of directorial images, where the language of literary text is translated into visual metaphors created on stage by a director. Due to this quality, some critics have argued that Lithuanian theatre has been demonstrating postdramatic characteristics for a long time. However, one should note that visual metaphors of modern Lithuanian theatre have been based on and controlled by literary text and never quite established a more autonomous and self-contained visuality. Dramatic text remained the point of departure whether the director chose to illustrate or concretise it, to transform or deform it. However, in post-Soviet Lithuanian theatre, these relations have been gradually turning discontinuous, their intensity often varied within the framework of the same performance. Fragmentary cracks, when images, departed from the roles of commentators or illustrators of textual meanings, turned into flashes of independent visions that were seen by the critics as an obvious shift towards a radical image-centric position or, to use the term of Hans-Thies Lehmann, postdramatic theatre. However, the recent performance Lokis (2017, Lithuanian National Drama Theatre) by Polish theatre artist Lukasz Twarkowski, produced twenty years after the initial introduction of the term postdramatic into the Lithuanian context, has paradoxically started a storm of divisive opinions in the Lithuanian theatre milieu. It became the focal point of discussions about the intrinsic character of Lithuanian theatre, especially its embedded attitudes towards drama text and acting-notoriously challenging factors for many international collaborations. The article analyses the ongoing debates about the term postdramatic theatre and its interpretations in Lithuanian theatre criticism, taking the example of Lokis as a case study.

Keywords: Lithuanian theatre, postdramatic theatre, international collaboration, acting, visual metaphors.

In October 2017, Polish theatre critic Lukasz Drewniak wrote in the online journal Teatralny.pl: "Already for some time, we have been providing Lithuanian theatre with topics that help it come to terms with its own historical past, we have been introducing stage conventions that are so far unexploited or met with distrust on Lithuanian stage, we have been telling them which way to go." The article is titled "The Beast", and in it, Drewniak talks about the performance Lokis, produced in 2017 in the Lithuanian National Drama Theatre by Polish theatre artist Lukasz Twarkowski and his team. In his review of the piece, Drewniak writes: "Twarkowski came onto the Vilnius stage with a non-linear, multidimensional narrative, a multimedia spectacle, a hypnotising and engaging atmosphere. He demonstrated to Lithuanians a world as yet unseen and opened to them the true meaning of spectating." 2 Having read Drewniak's review, one could conclude that, twenty years after the initial introduction of the term postdramatic into the Lithuanian context, a performance that can truly be described as a fully-fledged post-dramatic experience was brought onto the stage of the Lithuanian National Drama Theatre by a Polish artist. Indeed, autonomous, self-contained, and detached visuality of Lokis, together with its choreographic characteristics and non-acting techniques, its heterogeneous structuring of theatrical elements and decentred modeling of the stage space, has started a storm of divisive opinions in the Lithuanian theatre milieu. It became the focal point of discussions about the intrinsic character of Lithuanian theatre, especially its embedded attitudes towards drama text and acting, already a notoriously limiting and challenging factor for many international collaborations. 
Since its establishment, Lithuanian professional theatre has always existed in between or at the intersection of two powerful theatrical traditions: the pre-war modern Russian theatre school and the Western tradition of theatre art. The new generation of theatre artists that made their debuts after the restoration of the Independence attempted to mix the traditions of Lithuanian theatre with emerging global tendencies, thus creating the hybrid character of contemporary Lithuanian performances, where debris of the modernist canon mixed with the Soviet theatre traditions and contemporary Western theatre practices are linked together or juxtaposed. ${ }^{3}$ At the same time, different attitudes towards the theatrical traditions from the Soviet era-mainly the logocentric positioning of text and a strong tradition of the theatre of the auteur, where a director's vision becomes the central axis of a performance, as well as the system of realistic psychological acting centred around the Stanislavskian notion of emotional truth-became increasingly visible, raising a question of whether it is possible to talk about a radical break with, a transformation, or a continuation of these traditions in post-Soviet Lithuanian theatre.

Another important question was centred around transnational influences, namely the effects of postmodernist aesthetics reaching Lithuania through international contacts, festivals, collaborations, and texts. Similarly to other post-Soviet countries, the transition from the modern to the postmodern in Lithuanian theatre had a fluid character with no radical attempts to discard the modernist (Soviet) tradition once and for all. However, one of the essential transformations that critics and theatre scholars have observed during the first decades of the Independence was the changing relationship between text and image on the Lithuanian stage.

Lithuanian theatre has always been known for its visual metaphors and dramaturgy of directorial images, where the language of literary text is translated into visual metaphors created on stage by a director. Due to this quality, some critics have argued that Lithuanian theatre has always been postdramatic and, already in the Soviet period (in the 60s and the 70s), one would have been able to count many postdramatic features in the works of such Lithuanian stage directors as Jonas Vaitkus, Saulius Varnas, or Aurelija Ragauskaite, not to mention the performances by Eimuntas Nekrošius that were assumed postdramatic per se, because his works were mentioned by Hans-Thies Lehmann in his seminal book as an example of the postdramatic. ${ }^{4}$

However, one should note that visual metaphors of Soviet Lithuanian theatre were based and controlled by literary text and never quite established a more autonomous and self-contained visuality. For a long time, Lithuanian theatre was dominated by the oneway dynamics of "from text to visual metaphor", with small variations between the more text-centric and image-centric scales. Dramatic text remained the point of departure whether the director chose to illustrate or concretise it, to transform or deform it. However, in post-Soviet Lithuanian theatre, these relations have been gradually turning discontinuous, their intensity often varied within the framework of the same performance. Fragmentary cracks, when images departed from the roles of commentators or illustrators of textual meanings, turned into flashes of independent visions that were seen by the critics as an obvious shift towards a radical imagecentric position. During the first decade of the Independence, there were more than a few attempts to open up the theatrical landscape to the new representations that go "beyond drama".

The first performances by stage director Oskaras Koršunovas Ten būti čia (Paūméjimai) (There to be Here (The Exacerbations), 1990), Sene (The Old Woman, 1992), Labas Sonia Nauji metai (Hello Sonia New Year, 1994), Sené 2 (The Old Woman 2, 1994), described by theatre critics as "a challenge to the Lithuanian theatre tradition", marked the emergence of a different kind of relations between textual and visual elements in theatre. ${ }^{5}$ The starting point of the creation of these performances was not so much text but rather an urge to rediscover theatre's vitality, its power of affection. According to Koršunovas, "we wanted to escape what is almost inescapable in modern theatre: didactics, moralizing and metaphors of meaning. (...) It is very important not to be tied to literature or to any system of meanings." Text in these performances was not used as a basis for the plot but rather as one of the many elements 
of theatrical expression. Linearity of a given system of signification was disturbed, thus creating new dissonant patterns of meaning. In this context, it is also worth to mention the productions of the Miraklis theatre troupe and Benas Šarka as examples of having approached the postdramatic position closer than anyone else has by discovering other means of theatrical communication: namely the body and the space. Creative activities of Šarka demonstrated performative and fluid corporeality-the body as text, while the short-lived projects of Miraklis sustained the understanding of place as mobile and dynamic text, revived and re-created through performative action.

Despite these tendencies, Lithuanian critics interpreted the notorious predisposition of Lithuanian theatre toward visual narration as lack of courage, escapism, and inability to voice and articulate the state of the changing post-Soviet reality. Openness and elusiveness of visual narrative was considered to be an anti-social strategy, a way to escape from the straightforwardness of a critical message, a refusal to deal with the emerging political, social, or even cultural concerns of the moment. Even while trying to portray the transforming relationships between the visual and the textual in contemporary Lithuanian theatre as a result of the continuation of a far-reaching theatrical tradition, in the long run, the critics were forced to acknowledge the immanent difference or, as some said, the alien (foreign) character, the otherness of these postmodern performances. This new tendency was articulated by the critics as "aggressive visuality"7 or "negligence towards the text". Some even thought that this new approach to textual and performative elements in contemporary Lithuanian theatre was only a fragmentary digression from otherwise logocentric, psychologicallybased conventions of the modern theatre tradition. Nevertheless, precisely the alien/different character of these performances forced theatre critics to look for ways to adequately articulate the nature of new visuality or new textuality, and the term postdramatic fell right into their hands as a useful tool to map the changing territory of post-Soviet Lithuanian theatre.

The term postdramatic theatre was initially introduced into the Lithuanian vocabulary of theatre research in 1997 by Lehmann himself during the course of his seminars and lectures at Vytautas Magnus University. As a result, the term started circulating in the Lithuanian academic milieu with the help of the graduates of this course and was applied in the analysis of drama texts, acting, and theatrical space. ${ }^{9}$ This term allowed the critics to interpret the changing representations of Lithuanian theatre in quite a different dimension. Most importantly the concept of the postdramatic helped move debates from the realm of ethics to the field of aesthetics: the new visual language was interpreted not as an ethical position, as in the case of the phenomenon of Aesopian language, but as an aesthetic strategy.

While talking about interpretations of the concept of the postdramatic in the Lithuanian theatrical context, we have to bear in mind several aspects. Firstly, the sound of the term postdramatic was very pleasant and soothing to the ear of a Lithuanian theatre critic as it still contained the word "dramatic", demonstrating a latent relationship with the literary, at least semantically. Secondly, the usage of this term in the discourse of Lithuanian theatre studies was permeated with a modernist anxiety for the integrity of theatre. Some theatre scholars saw the postdramatic as a potential threat to the aesthetic autonomy and identity of theatre. This position was deeply embedded in the modernist binarism between literary and visual theatre or, quoting Jurij Lotman, between the theatre of prose and the theatre of poetry. ${ }^{10}$

An example of this binarism can be found in an article written by Audronis Liuga in 2005, where he talks about "the dangerously attractive zone of visual theatre". 11 He uses the terms postdramatic theatre and theatre of images as identical concepts. According to the critic, the ideology of such theatre contrasts visual and literary categories of performance and questions the fundamental notions of role and action. ${ }^{12}$ Liuga narrows down the characteristics of the postdramatic to heterogeneous relations between the performance elements as they are disconnected and deconstructed in the process. $\mathrm{He}$ operates within the realm of the binary logic as he states that this kind of theatre disrupts the notion of the role and replaces it with an actor as a sign in a performance's landscape. According to Liuga, this is exactly the danger zone where a new theatricality is 
being constructed on the one hand, but theatre risks losing its object and artistic particularity on the other. Liuga warns that, while raising fundamental questions about action and acting, image and text, and limits of their transformations, postdramatic theatre risks becoming just a small / marginal part of the contemporary cultural landscape, unable to reach minds and hearts of wider audiences. ${ }^{13}$

Paradoxically, precisely the same arguments were repeated by critical voices after the premier of Lokis. "Loss of meaningful communication", "a triumph of image, technology, and masses over the destiny of an individual man", "beautiful emptiness", "predominance of multimedial form over clarity of narrative": these are just a few examples that unconsciously mirror Liuga's arguments. ${ }^{14}$ Indeed, in Lokis, the grand spectacle was created by a polyphony of sounds, rhythms, images, multitudes of media, overlapping visual and aural narratives. The complicated structure of a sophisticated yet shocking and unsettling performance, where many layers of meaning intertwine, invited the spectators to delve deeper into the mysteries of Being and the enigmas of Human Nature. The performance is loosely based on the novel Lokis by Prosper Mérimée and the biographies of two artists: Bertrand Cantat, the lead singer of the French rock group Noir Désir, who killed his lover, famous French actress Marie Trintignant, while on a short stay in Vilnius, and visionary Lithuanian photographer Vitas Luckus, who committed manslaughter and suicide in his Vilnius home during the Soviet period. However, de-hierarchisation of theatrical means reduced the authority of logos, producing multidimensional narratives that proved to be quite difficult to grasp even for an audience that had been for a long time treated with allusiveness of metaphorical representations. Some perceived this strategy as an embodiment of networked and interconnected postindustrial society so crisscrossed by the flood of disconnected moments of communication that it is no longer able to bring together any meaningful or unified communication of signs.

For others, however, it was a possibility to finally admire a truly "different kind of theatre". One of the many enthusiastic admirers of Lokis, playwright and theatre critic Dovilè Statkevičienè proclaimed in her review: "The main driver of this performance is not dramaturgy but rather aural and visual constructs, which constitute a flawless audiovisual architecture (...) Finally, we can talk about theatre as ambience, as dynamics of stage structure, as scenic landscape." ${ }^{15}$ Another substantial point of antagonism set by Lokis was a form of "post-Stanislavskian post-psychological" style of acting. For some critics, the exposure of a material body on stage as well as the juxtaposition of acting (re-presenting the role) and non-acting (being present on stage) provoked critical questions about the nature of contemporary acting itself or, on a larger scale, the nature of presence in theatre. For others, however, it was yet another case of "foreign influence": alien, artificial, lacking psychological depth, and thus vindicating Liuga's prophecy about the redundancy of the actor in postdramatic theatre. As if having anticipated this criticism, the creators of Lokis included a small fragment of a staged press conference in the beginning of the performance in which the performer embodying stage director Twarkowsky (actor Vainius Sodeika) complains about confused Lithuanian actors constantly asking about the psychological background of their characters, clearly unable to shake off the constraints of the Stanislavskian notion of acting.

Indeed, for a long time the term "modified Stanislavsky's system" was the most relevant when describing the nature of acting in Lithuanian theatre. ${ }^{16}$ It is true that the leaders of Lithuanian stage directing-Vaitkus, Nekrošius, Rimas Tuminascreated their own individual methods of working with actors: Nekrošius supplemented the Stanislavskian urge for authenticity with choreographic physicality and body-object metaphors; Vaitkus infused it with physical and constructivist notions of performing, together with a strong emphasis on aural elements; Tuminas-with grotesque and theatricality; Koršunovas-with postmodern aesthetics. However, the psychological motivation of the role remained the focal point of acting on Lithuanian stage.

Paradoxically, precisely this feature of Lithuanian theatre became the usual target of all international collaborations: the challenge to convert Lithuanian actors to the new forms of acting was approached differently by various artists but remained a stumbling 
stone even for the brightest minds. Kristian Smeds, Krystian Lupa, Arpad Schilling, Valters Silis, Jānis Balodis, Vladislavs Nastavsevs all struggled trying to convince (in various ways) Lithuanian actors to test different ways of being on stage. However, precisely the blossoming eagerness of some Lithuanian actors to open themselves up to different concepts of acting-to embrace the play with distances between one's identity and a role, to be more flexible and able to employ various acting techniques in one performance, to approach daringly "open" texts, fragmentary characters, postdramatic theatre practices, or non-acting techniques-can be defined as one of the major achievements of international collaborations-one more successful than the others. Furthermore, one could state that the best practices of international collaboration are not those that champion the mimetic adoption of an imported model but rather those that help depart from the already consecrated modes of making art and move towards disruptive ways of disagreement. Therefore, intercultural exchange should no longer be understood as a question of dialectics between text and context but rather as a mediation between different cultural backgrounds, traditions, and methods of acting.

\section{References}

Balevičiūtè, Ramunè. "Dar vienas žvilgsnis ị psichologinị realizmą ir jo įspaudus lietuvių teatre." Menotyra 14: 4 (2007): 47-56.

Boyle, Michael Shane, Matt Cornish, and Brandon Woolf, eds. Postdramatic Theatre and Form. London: Bloomsbury, 2019.

Braškyte, Alma. "Nesam tokie, kokie norime būti." 7 meno dienos, September 22, 2017. http://www.menufaktura. $\mathrm{lt} / \mathrm{?} \mathrm{m}=1025 \& \mathrm{~s}=61352$.

Brukštutè, Milda. "İelektrinta tiesos vegetacija." 15 min.lt, September 26, 2017. http://www.menufaktura. $\mathrm{lt} / ? \mathrm{~m}=1025 \& \mathrm{~s}=61353$.

Daunoravičiūtè, Ingrida. "Kas slypi už vizualumo 'triumfo'?" Kultūros barai 6 (1999): 29.

Drewniak, Lukasz. "Zwierzę." Teatralny.pl, October 2, 2017. http://www.teatras.lt/lt/spektakliai/anka_ herbut_lokis/

Jauniškis, Vaidas. "Vakarèlis teatro kèdeje." vz.lt, September 22, 2017. http://www.menufaktura. $\mathrm{lt} / \mathrm{?} \mathrm{m}=1025 \& \mathrm{~s}=61351$.

Jürs-Munby, Karen, Jerome Carroll, and Steve Giles, eds. Postdramatic Theatre and the Political: International Perspectives on Contemporary Performance. London, New York: Bloomsbury, 2013.
Klich, Rosemary, and Edward Scheer. Multimedia Performance. London: Malgrave Macmillan, 2012.

Lehmann, Hans-Thies. Postdraminis teatras. Vilnius: Menų spaustuvé, 2010.

Liuga, Audronis. "Agresyvaus vaizdo teatras." 7 meno dienos, August 2, 1996, 2.

Liuga, Audronis. "Apie teatrinio vaizdo prigimti ir pavojingai patrauklią vaizdų teatro zoną." Kultūros barai 8/9 (2005): 50-56.

Staniškytè, Jurgita. "Between East and West: Intercultural Challenges and Problem of Authenticity in Contemporary Lithuanian Theatre." Lituanus 2 (2010): 21-29.

Staniškyte, Jurgita, Rasa Vasinauskaite, Edgaras Klivis, and Martynas Petrikas. Post-Sovietinis Lietuvos teatras: istorija, tapatybe, atmintis. Vilnius: VDA Leidykla, 2014.

Statkevičienè, Dovilè. "Šokantys lokio kūnai." menufaktura.lt, September 17, 2017. http://www. menufaktura.lt $/$ ?m=1025\&s=61349.

Steiblytė, Kristina. "İvaizdis dar ne viskas." lteatras.lt, January 14, 2018. http://www.menufaktura.lt/?m= $1025 \& s=61393$.

Vasinauskaite, Rasa, ed. The Theatre of Oskaras Koršunovas: Interviews and Articles. Vilnius: Baltos Lankos, 2002.

\section{Notes}

1 Lukasz Drewniak, “Zwierzę," Teatralny.pl, October 2, 2017, http://www.teatras.lt/lt/spektakliai/ anka_herbut_lokis/

2 Ibid.

3 For a detailed discussion, see Jurgita Staniškyte, "Between East and West: Intercultural Challenges and Problem of Authenticity in Contemporary Lithuanian Theatre," Lituanus 2 (2010): 21-29.

4 Hans-Thies Lehmann, Postdraminis teatras (Vilnius: Menų spaustuve, 2010), 141.

5 Jurgita Staniškyte, Rasa Vasinauskaitė, Edgaras Klivis, and Martynas Petrikas, Post-Sovietinis Lietuvos teatras: istorija, tapatybe, atmintis (Vilnius: VDA Leidykla, 2014), 354.

$6 \quad$ The Theatre of Oskaras Koršunovas: Interviews and Articles, ed. Rasa Vasinauskaite (Vilnius: Baltos Lankos, 2002), 45-47.

7 Audronis Liuga, "Agresyvaus vaizdo teatras," 7 meno dienos, August 2, 1996, 2.

8 Ingrida Daunoravičiūte, "Kas slypi už vizualumo 'triumfo'?" Kultūros barai 6 (1999): 29.

9 For examples of this approach, see Nomeda Šatkauskienè, Dramos teksto sklaidos ypatumai: teoriniu paradigmu kaita ir ju analizé: daktaro disertacijos santrauka (Kaunas: Vytauto Didžiojo universiteto leidykla, 2002); Rūta Mažeikienè, Vaidmens sampratos transformacija: aktoriaus kūryba šiuolaikiniame Lietuvos dramos teatre: daktaro disertacijos santrauka (Kaunas: Vytauto Didžiojo universiteto leidykla, 2005).

10 Audronis Liuga, "Apie teatrinio vaizdo prigimtị ir pavojingai patrauklią vaizdų teatro zoną," Kultūros barai 8/9 (2005): 51.

11 Ibid., 50-56. 
12 Ibid., 54.

13 Ibid., 55.

14 For detailed reviews of Lokis, see Vaidas Jauniškis, "Vakarèlis teatro kèdèje," vz.lt, September 22, 2017, http://www. menufaktura.lt/? $\mathrm{m}=1025 \& \mathrm{~s}=61351$; Milda Brukštute, "İelektrinta tiesos vegetacija," $15 \mathrm{~min}$. lt, September 26, 2017, http://www.menufaktura. lt/?m=1025\&s=61353; Alma Braškyte, "Nesam tokie, kokie norime būti," 7 meno dienos, September 22, 2017, http://www.menufaktura.lt/?m=1025\&s=61352; Kristina Steiblyte, "İvaizdis dar ne viskas," lteatras.lt, January 14, 2018, http://www.menufaktura.lt/?m=1025\&s=61393.

15 Dovilè Statkevičienè, "Šokantys lokio kūnai," menufaktura.lt, September 17, 2017, http://www. menufaktura.lt $/ ? \mathrm{~m}=1025 \& \mathrm{~s}=61349$.

16 Ramunè Balevičiūte, "Dar vienas žvilgsnis i psichologinį realizmą ir jo ịspaudus lietuvių teatre," Menotyra 14/2 (2007): 47-56.

\section{Jurgita STANIŠKYTÉ}

Vytauto Didžiojo universitetas, Kaunas, Lietuva

\section{TARP (NE)MATOMŲ İTAKŲ IR (NE)GRYNŲ TRADICIJŲ: HIBRIDINIS LIETUVOS TEATRO POSTDRAMATIŠKUMAS}

\section{Santrauka}

Moderni Lietuvos teatro režisūra garsèja vizualių metaforų kalba ir režisūrinių îvaizdžių dramaturgijos sklaida. Dèl šios priežasties kai kurie Lietuvos teatro kritikai teigè, kad postdraminès savybès nuo seno būdingos Lietuvos teatrui. Vis dèlto kalbant apie teksto transformacijas postsovietiniame Lietuvos teatre, neretai kur kas svarbiau atskirti moderniam Lietuvos teatrui charakteringą vizualių režisūrinių metaforų dramaturgiją, būdingą vyresniosios kartos režisierių darbams, ir postdraminio teatro apraiškas. Iš tiesų pastaraisiais dešimtmečiais Lietuvos teatre daugejo spektaklių, kuriuose vaizdas ar veiksmas daugiau ar mažiau perimdavo semantinę galią. Vis dèlto dažnai tai buvo tik „postdraminiai fragmentai“" gana konvencionalioje ar net dramo-centrineje spektaklio struktūroje. 2017 m. - dvidešimt metų po postdraminio teatro sąvokos atsiradimo Lietuvos teatrologijos žodyne - Lietuvos nacionaliniame dramos teatre pastatytas spektaklis „Lokis“, režisuotas lenkų menininko Lukaszo Twarkowskio, iplieskẻ diskusijų audrą, taip atnaujindamas svarstymus apie teksto ir vaizdo santykių dinamiką bei jų interpretavimo tradiciją Lietuvos teatre. Pasitelkus „Lokio“ atveji, straipsnyje nagrinejjama postdraminio teatro sampratos refleksija Lietuvos teatrologijoje, siekiant nužymėti gilesnes šių interpretacijų priežastis ir jų sąsajas su šiuolaikine Lietuvos teatro praktika.

Reikšminiai žodžiai: Lietuvos teatras, postdraminis teatras, tarptautinis bendradarbiavimas, vaidyba, vaizdinès metaforos.

\section{Jurgita STANIŠKYTÉ}

Jurgita Staniškytė, PhD, heads the Faculty of Arts and is a Full Professor of Theatre Studies Department at Vytautas Magnus University (Kaunas, Lithuania). She has published numerous scientific and critical articles as well as monographs on contemporary Lithuanian theatre in the context of the processes of

Baltic stage art, performative aspects of post-Soviet Lithuanian culture, creative communication, and audience development. Jurgita Staniškyte is also a Board Member of HERA (Humanities in the European Research Area). She was recently elected to the position of Chairwoman of the Board of Kaunas European Capital of Culture 2022. 